\title{
Effects of using Tamarindus indica Seeds as a natural coagulant aid in landfill leachate treatment
}

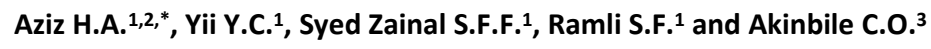 \\ ${ }^{1}$ School of Civil Engineering, Engineering Campus, Universiti Sains Malaysia, 14300 Nibong Tebal, Penang, Malaysia \\ ${ }^{2}$ Solid Waste Management Cluster, Science and Technology Research Centre, Engineering Campus, Universiti Sains Malaysia, 14300 \\ Nibong Tebal, Penang, Malaysia \\ ${ }^{3}$ Department of Agricultural and Environmental Engineering, Federal University of Technology, Akure, Nigeria \\ Received: 18/09/2017, Accepted: 18/03/2018, Available online: 27/07/2018 \\ *to whom all correspondence should be addressed: e-mail: cehamidi@usm.my
}

\begin{abstract}
Uncontrolled landfill leachate generation portends danger to the environment and aquatic ecosystem, especially without prior treatment before discharge. The application of Al-based coagulants, such as polyaluminum chloride (PACl), has the potential of introducing Al residuals into water bodies. Therefore, an alternative natural coagulant was recommended to reduce the usage of Al-based coagulants. In this study, a coagulation-flocculation process using the combination of $\mathrm{PACl}$ as coagulant and Tamarindus indica seed (TiS) as coagulant aid was used in treating the landfill leachate from the Alor Pongsu Landfill Site in Malaysia. Some of the optimum operational conditions determined were the $\mathrm{pH}$ and dosage of the coagulant aid, and their effect was considered on parameters, such as suspended solids (SS), color, and COD, using standard jar test procedures. The combination of TiS flocculant reduced the dosage of $\mathrm{PACl}$ coagulant from $5,000 \mathrm{mg} / \mathrm{L}$ to $2,750 \mathrm{mg} / \mathrm{L}$ with removal efficiencies of $99.3 \%, 97.3 \%$, and $67.4 \%$ for SS, color, and COD, respectively.
\end{abstract}

Keywords: Tamarindus indica; PAC1; landfill leachate, coagulant, coagulant aid

\section{Introduction}

Landfill leachate is generally referred to as a complex liquid that may contain a large amount of organic matters, ammonia-nitrogen, suspended solids (SS), chlorinated organic and inorganic salts, and heavy metals (Foo and Hemeed, 2009; Bashir et al., 2010). The disposal of landfill leachate can be a source of severe pollution, especially for soil, water, and groundwater contamination (El-Salam and Abu Zuid, 2015). Similarly, public health hazards may also be caused by the discharge of untreated landfill leachate, especially into water bodies (Akinbile et al., 2012; Al Hamadani et al., 2011; Aziz et al., 2011). In an attempt to prevent an occurrence of this scenario, related government regulatory agencies are becoming more stringent and restrictive in the enforcement of environmental rules and regulations concerning the monitoring of contaminants from leachate waste streams (Maizatun, 2011). Adequate and appropriate landfill leachate treatments have been widely proposed to alleviate challenges associated with untreated leachate (Akinbile et al., 2016; Amuda et al., 2006; Aziz and Mojiri, 2014). Many well-documented treatment techniques are available, including biological, physical, or physicochemical methods (Akinbile et al., 2016; Aziz et al., 2011: Alias et al., 2010). Several types of physicochemical treatments, such as chemical precipitation, coagulation-flocculation, adsorption, ion exchange, and ammonium stripping, are available (Kamaruddin et al., 2013; Turovsky and Mathai, 2006). The coagulation-flocculation process is a comparatively simple and widely applied technique used in water and wastewater treatment (Aziz and Mojiri, 2014; Aziz et al., 2007; Amuda et al., 2006) and has also been proven as a cost-effective treatment approach in landfill leachate treatment (Rajaram et al., 2011). The mechanism involves charge neutralization by adding coagulants to destabilize negatively charged colloids for the agglomeration of fine particles and colloids into large particles, thereby reducing turbidity, natural organic matter, and other soluble organic and inorganic pollutants in wastewater (Teh et al., 2016). The commonly used commercial coagulants are aluminum sulfate (alum), polyaluminum chloride ( $\mathrm{PACl})$, ferrous sulfate, ferric chlorosulfate, and ferric chloride (Lee, 2013). Although inorganic coagulants are generally effective, some drawbacks are observed related to the high amount of metal ions in sludge (Mishra, 2016). On the contrary, natural coagulants are found to produce a relatively low sludge volume and are safe to humans compared with inorganic coagulants (Madhukar and Yogesh, 2013). Although natural coagulants have been widely applied in wastewater treatment (Santos et al., 2016; Kos, 2016), their application in landfill leachate treatment is limited despite their abundance, relatively low cost, and being environmentally friendly (Meraz et al., 2016).

Tamarind is widely spread throughout Asia and Southeast Asia, especially in India and Thailand where the species is planted in large plantation scales and is economically important. In comparison with these two countries, 
tamarind is not commonly found or seen throughout Malaysia, except in the northern region where the ecological condition is better suited than that in the other regions. No actual data are available on the production and area of tamarind plantation in Malaysia. Tamarind is mostly grown in small-scale plantations. It is mainly cultivated in Penang and Kedah. Obtaining precise data on the production and acreage of this species is relatively difficult due to its small production. Furthermore, most of the fruits are either collected from the wild by rural people or harvested in isolated areas. Some of the tamarinds are also imported and repacked locally. A number of food factories process and sell tamarinds in the form of seedless paste, in which the seed is disposed untreated. The actual number of factories is not available. As tamarind is one of the most common ingredient added in many dishes, its wide usage is expected for over 28 million of the current population. Furthermore, tamarind is a common ingredient in Malay, Indian, and Chinese cuisines in Malaysia and a "must-have" ingredient in almost all dishes.

Several studies have been conducted on the application of Tamarindus indica seed (TiS) in the coagulationflocculation method, as well as adsorption. Mostly, the application of TiS in the coagulation-flocculation process involves the use of low concentrated wastewater. For example, Phani Madhavi and Rajkumar (2013) used TiS powder for the treatment of low turbid wastewater. They achieved $78 \%$ removal turbidity at optimum $\mathrm{pH}$ of 8 and optimum dosage of $150 \mathrm{mg} / \mathrm{L}$. Murugan and Subramanian

Table 1. APLS Raw Leachate Characteristics

\begin{tabular}{ccccc}
\hline Parameters & Unit & Min & Max & Average \\
\hline Temperature & ${ }^{\circ} \mathrm{C}$ & 28.19 & 38.85 & 31.34 \\
\hline $\mathrm{pH}$ & - & 7.78 & 8.12 & 7.99 \\
\hline $\mathrm{DO}$ & $\mathrm{mg} / \mathrm{L}$ & 0.05 & 0.27 & 0.17 \\
\hline $\mathrm{COD}$ & $\mathrm{mg} / \mathrm{L}$ & 3610 & 4113 & 3925 \\
\hline $\mathrm{BOD}_{5}$ & $\mathrm{mg} / \mathrm{L}$ & 107 & 176 & 131 \\
\hline $\mathrm{BOD}_{5} / \mathrm{COD}$ & - & 0.03 & 0.05 & 0.03 \\
\hline $\mathrm{NH}_{3}-\mathrm{N}$ & $\mathrm{mg} / \mathrm{L}$ & 1010 & 1480 & 1296 \\
\hline $\mathrm{TSS}$ & $\mathrm{mg} / \mathrm{L}$ & 356 & 478 & 397 \\
\hline $\mathrm{TDS}$ & $\mathrm{g} / \mathrm{L}$ & 9.13 & 9.61 & 40.35 \\
\hline Turbidity & $\mathrm{NTU}$ & 33.4 & 49.9 & 13787 \\
\hline Colour & $\mathrm{Pt} \mathrm{Co}$ & 10317 & 18733 & 16128 \\
\hline Conductivity & $\mu \mathrm{S} / \mathrm{cm}$ & 15134 & 18413 & -23.2 \\
\hline Zeta Potential & $\mathrm{mV}$ & -24.8 & -21.6 & 0.09 \\
\hline Chromium $(\mathrm{Cr})$ & $\mathrm{mg} / \mathrm{L}$ & 0.03 & 0.15 & 9.96 \\
\hline Iron $(\mathrm{Fe})$ & $\mathrm{mg} / \mathrm{L}$ & 8.66 & 10.91 & 0.26 \\
\hline Manganese $(\mathrm{Mn})$ & $\mathrm{mg} / \mathrm{L}$ & 0.15 & 0.38 & 0.46
\end{tabular}

\subsection{Preparation of TiS as Coagulant}

Fresh $T$. indica fruits at $500 \pm 0.5 \mathrm{~g}$ were obtained from the local market and prepared using distilled water. The seeds were then oven-dried for $1 \mathrm{~h}$ at $105{ }^{\circ} \mathrm{C}$ and, once weakened, the seeds were crushed using a mortar and pestle to separate the seed husks and kernels. The crushed kernels were oven-dried for $1 \mathrm{~h}$ to ensure that the seeds
(2006) applied tamarind seeds as an absorbent in water treatment method. Total defluoridation and subsequent regeneration of adsorbent were performed with a household water filter and fixed bed column for domestic and industrial applications, respectively, and maximum defluoridation was achieved at $\mathrm{pH} 7$.

The focus of previous studies when using TiS as coagulants in the coagulation-flocculation process has been mostly for the treatment of turbid or wastewater, whereas any utilization for leachate treatment, either as a primary coagulant or as a flocculant, is hardly available. Therefore, the main motive of this study is on the effectiveness of utilizing TiS as a coagulant for landfill leachate with the combination of $\mathrm{PACl}$ in removing SS, color, and COD. This study also aims to determine the optimum dosage of TiS and $\mathrm{PACl}$ as coagulants for landfill leachate treatment by conducting performance evaluation on the parameters of SS, color, and COD.

\section{Materials and methods}

\subsection{Leachate Sampling and Characterization}

Leachate samples were collected from the Alor Pongsu Landfill Site (APLS) in Bagan Serai, Perak, Malaysia from January to April, 2016. Sampling was conducted using the grab sampling method, whereas preservation was performed in accordance with the Standard Methods for the Examination of Water and Wastewater (APHA, 2005). Table 1 presents the initial characteristics of the six leachate samples obtained. 
coagulant/flocculant for the jar test experiments (Alias et al., 2010).

\subsection{Characterization of Leachate and TiS as a Function of $\mathrm{pH}$}

In determining the effect of $\mathrm{pH}$ on the zeta potential and particle size of the leachate and TiS, the leachate samples and TiS solutions were separately titrated using $0.5 \mathrm{M} \mathrm{HCl}$ and $0.5 \mathrm{M} \mathrm{NaOH}$ within a $\mathrm{pH}$ range of 2-12 under continuous agitation. Zetasizer Nano ZS was used in measuring the zeta potential and particle size in triplicate runs. A sample at $1 \mathrm{~mL}$ was administered into the capillary cell by using a pipette and placed into the Malvern Zetasizer Nano ZS. During measurement, samples were assayed by a $633 \mathrm{~mm} \mathrm{He}-\mathrm{Ne}$ laser beam using dynamic light scattering method with a scattering angle of $173^{\circ}$ (Omar, 2015). The instrument software program was run, and the zeta potential value was generated using Smoluchowski equation. For particle size measurement, a transparent, disposable cuvette was used in place of the capillary cell. Different standard operating procedures were used for the measurement of zeta potential and particle size. The graphs of two $y$-axes consisting of zeta potential and particle size versus $\mathrm{pH}$ value were generated separately for leachate and TiS. From the results obtained, the values of IEP and PZC for the leachate and TiS were identified.

\section{$2.4 \quad$ Jar Test}

Coagulation test was performed by using a jar test equipment (SW6 Stuart Bibby Scientific Limited, UK). $\mathrm{NaOH}$ and $\mathrm{HCl}$ at $3 \mathrm{M}$ each were used to adjust the $\mathrm{pH}$ sample. The test involved rapid mixing, slow mixing, and sedimentation in a batch process. For jar tests using $18 \%$ $\mathrm{PACl}$ as the main coagulant, the rapid mixing was set at 200 rpm for $3 \mathrm{~min}$ and slow mixing at $40 \mathrm{rpm}$ for $30 \mathrm{~min}$; the settlement was $30 \mathrm{~min}$ (Zainol et al., 2013). Meanwhile, the operational conditions of the jar tests using TiS as the main coagulant were rapid mixing at $100 \mathrm{rpm}$ for $8 \mathrm{~min}$ and slow mixing at $30 \mathrm{rpm}$ for $20 \mathrm{~min}$, and the settlement was $30 \mathrm{~min}$ (Muyibi et al., 2002). Leachate samples at $500 \mathrm{~mL}$ were filled into six beakers and agitated simultaneously while varying the rotational speed and allowing the simulation of different mixing intensities and resulting flocculation process (Mokhtar et al., 2011).

\section{Results and discussion}

\subsection{Characteristics of Leachate Zeta Potential and} Particle Size as a Function of $\mathrm{pH}$

A general but gentle decline was observed in the trend of the zeta potential of leachate when compared with the observed increase in $\mathrm{pH}$. This trend suggested that the zeta potential was closely dependent on the $\mathrm{pH}$ value of the leachate (Fig. 1). The zeta potential decreased with the increase in pH value. Lin et al., (2013) remarked that a strong surface charge in the particle could result in a significant mutual repulsion. Similarly, an irregular sinusoidal trend was observed in the behavior of the particle size distribution of the leachate with respect to the increasing $\mathrm{pH}$ ranging from 2 to 12 , as shown in Fig. 1. At an approximately natural $\mathrm{pH}$ value of 8 for the leachate, the zeta potential was found to be at $-23.43 \pm 1.46 \mathrm{mV}$, which indicated that the surface charge of the leachate was negatively charged. For the coagulant to be highly effective, the zeta potential is required to be higher than $+20 \mathrm{mV}$, such that it can neutralize and attract the particles to form flocs, which agrees with the findings of AlHamadani et al., (2011). As soon as the $\mathrm{pH}$ was adjusted to the acidic region, the surface charge of the leachate became less negative and approached $-5 \mathrm{mV}$ (Fig. 1), which caused the particle size of the leachate to increase. In view of the zeta potential between $\mathrm{pH}$ values of 4 and 7 , stabilization in the particle size of the leachate was observed, whereas the zeta potential remained the same at an approximate value of $-20 \mathrm{mV}$. Within the alkaline region of $\mathrm{pH}$ values of 8 and 11 , the particle size of the leachate remained unchanged at an approximate value of $320 \mathrm{~d} . \mathrm{nm}$, whereas the zeta potential of the leachate was constantly decreasing and becoming highly negatively charged. Electrostatic repulsion of the particles occurred, thereby increasing the size of particles. However, when the $\mathrm{pH}$ value approached 12 , the particle size of the leachate decreased to $246 \mathrm{~d} . \mathrm{nm}$ and tended to reduce further under high alkaline $\mathrm{pH}$ value of 14 , which agrees with the findings of Kamaruddin et al., (2015).

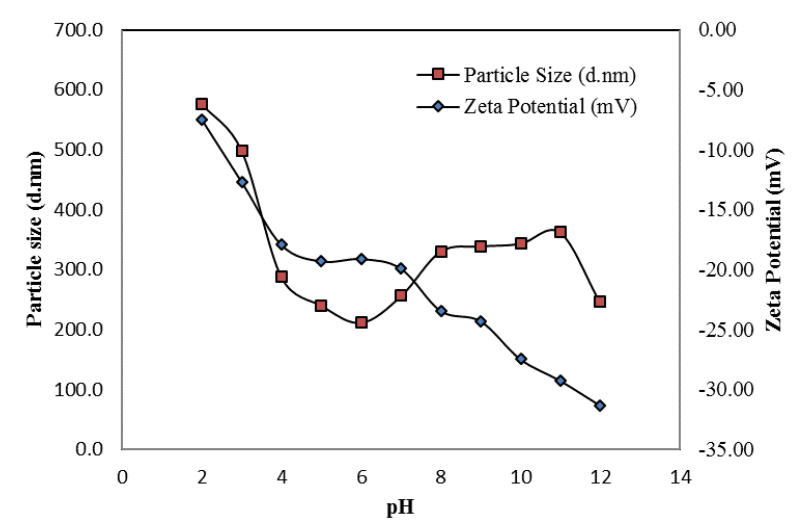

Figure 1. Characteristics of Leachate as a function of $\mathrm{pH}$

\subsection{Characteristics of TiS Zeta Potential and Particle Size as a Function of $\mathrm{pH}$}

Fig. 2 shows the characteristics of the zeta potential and particle size for TiS under varying $\mathrm{pH}$ values of 2-12. A slightly distinctive decline in the zeta potential of TiS was observed from the $\mathrm{pH}$ value of 2-11. Meanwhile, an extremely sharp decline was recorded for $\mathrm{pH}$ values of $11-$ 12 with the zeta potential values decreasing from $-0.3 \mathrm{mV}$ to $-36.83 \mathrm{mV}$ (Fig. 2). Moreover, a sharp contrast was observed in the particle size when a mild undulating trend was noticed for the $\mathrm{pH}$ values from 2 to 8 . The value range of the particle size was from $17 \mu \mathrm{m}$ to $38 \mu \mathrm{m}$. From pH values of $8-12$, a sudden increase was observed as the particle size increased from $20 \mathrm{~m}$ to $169.874 \mathrm{~m}$ (Fig. 2). Overall, the behavioral trend of the particle size of TiS was the opposite of the zeta potential trend, where the particle size of TiS increased with the $\mathrm{pH}$ value. At $\mathrm{pH} 2$, the zeta potential was positive at $1.87 \pm 0.49 \mathrm{mV}$, whereas the 
particle size recorded was $31.879 \mathrm{~m}$. Thereafter, the zeta potential tended toward zero charge as the $\mathrm{pH}$ value increased. Within the alkaline region, the zeta potential fluctuated from the range of $-2.50 \mathrm{mV}$ to $-4.00 \mathrm{mV}$, whereas the particle size increased rapidly with an increasing $\mathrm{pH}$ value. All these observations agree with the findings of Aziz et al., (2011).

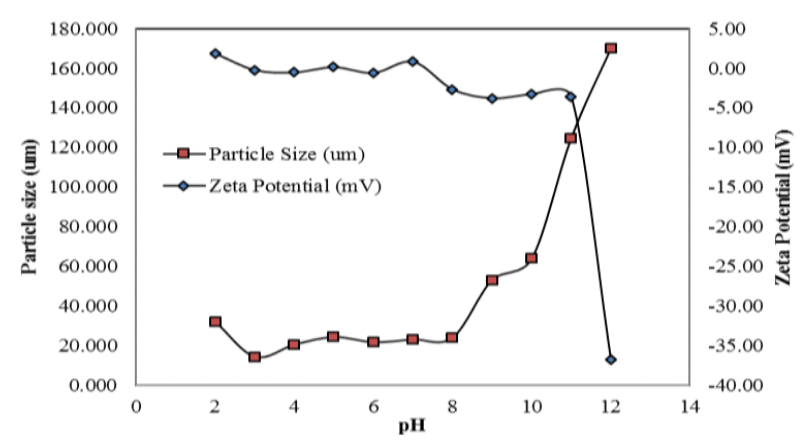

Figure 2. Characteristics of Tamarindus indica Seeds (TiS) as a function of $\mathrm{pH}$
3.3 Optimum Dosage for TiS as a Flocculant in the Removal of SS, Color, and COD

The optimum dosage of TiS as a flocculant was determined by using jar test procedures with rapid mixing at $200 \mathrm{rpm}$ for $3 \mathrm{~min}$, slow mixing at $40 \mathrm{rpm}$ for $30 \mathrm{~min}$, and $30 \mathrm{~min}$ settlement (Zainol et al., 2013). The tests were conducted at $31.3^{\circ} \mathrm{C}$; the initial concentrations of SS, color, and COD were $397 \mathrm{mg} / \mathrm{L}, 13,787 \mathrm{Pt} \mathrm{Co}$, and 3,925 mg/L, respectively. Fig. 3 presents the removal efficiency of SS with various dosages of PACl as coagulant and TiS as flocculant. High efficiency in SS removal was observed when specific quantities ranging between $3,000 \mathrm{mg} / \mathrm{L}$ and $4,000 \mathrm{mg} / \mathrm{L}$ of $\mathrm{PACl}$ were introduced with varied dosages of TiS into the leachate. From the figure, the introduction of a low $\mathrm{PACl}$ dosage of $2,750 \mathrm{mg} / \mathrm{L}$ with $2,000 \mathrm{mg} / \mathrm{L}$ of TiS was found to be highly efficient at $99.3 \%$ in removing SS from the leachate. Identical performance was achieved using 5,000 $\mathrm{mg} / \mathrm{L}$ of $\mathrm{PACl}$ as the sole coagulant, which provided a $99.5 \%$ removal efficiency. Ebeling et al., (2005) confirmed this high efficiency in a similar study conducted.

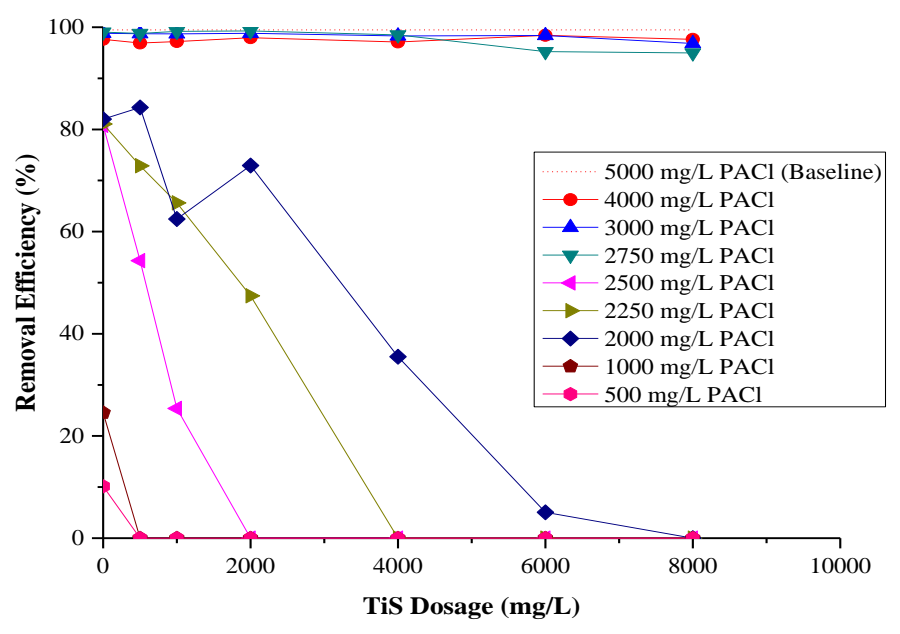

Figure 3. SS removal efficiency with varied dosage of PACl as coagulant and TiS as flocculant

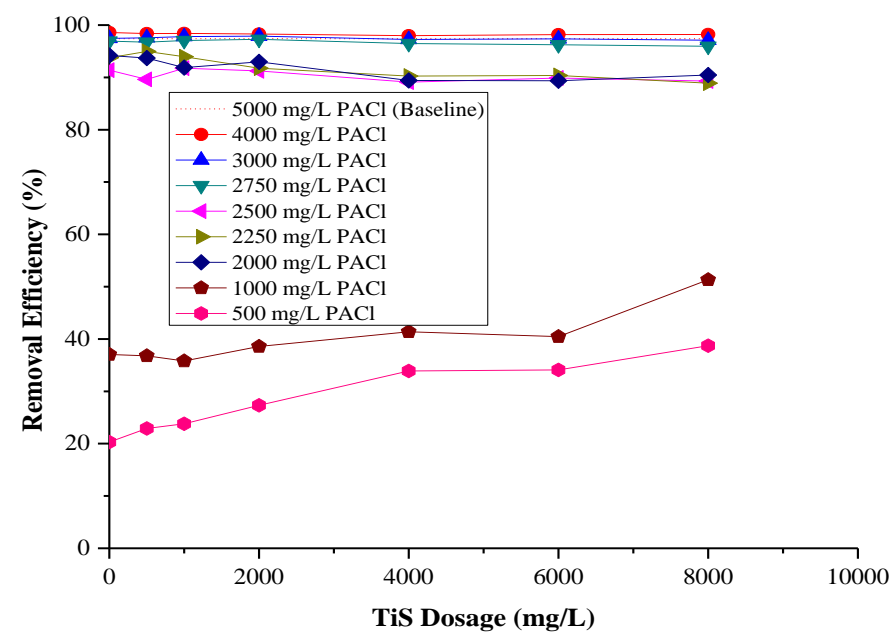

Figure 4. Colour removal efficiency with varied dosage of $\mathrm{PACl}$ as coagulant and TiS as flocculant

In the color removal (Fig. 4), using $2,000 \mathrm{mg} / \mathrm{L}$ of PACl with $2,000 \mathrm{mg} / \mathrm{L}$ of TiS as flocculants achieved $93.0 \%$ removal efficiency, whereas $97.4 \%$ removal efficiency was obtained when the initial TiS values were used with $5,000 \mathrm{mg} / \mathrm{L}$ of 
$\mathrm{PACl}$ as the sole coagulant. However, when the PACl dosage was lowered to $1,000 \mathrm{mg} / \mathrm{L}$ and below, the efficiency of color removal declined considerably and therefore confirmed the assertion of Aziz et al., (2007), who suggested that color in landfill leachate is mostly presented by organic matters with some unsolvable forms that reveal turbidity and SS.

The removal efficiency of COD by using various dosages of $\mathrm{PACl}$ as coagulant and TiS as flocculant was unsatisfactory, as shown on Fig. 5. Further increase in TiS dosages ironically further reduced the efficiency of COD removal. However, when comparing the removal efficiencies of using 2,750 $\mathrm{mg} / \mathrm{L}$ of PACl with $2,000 \mathrm{mg} / \mathrm{L}$ of TiS with using $2,750 \mathrm{mg} / \mathrm{L}$ of $\mathrm{PACl}$ only as the primary coagulant, the COD removal efficiency increased to $67.4 \%$ for the former and $73.6 \%$ for the latter. Further reduction in PACl dosage to $2,500 \mathrm{mg} / \mathrm{L}$ was observed to contribute to a $60 \%$ removal efficiency (Fig. 5).

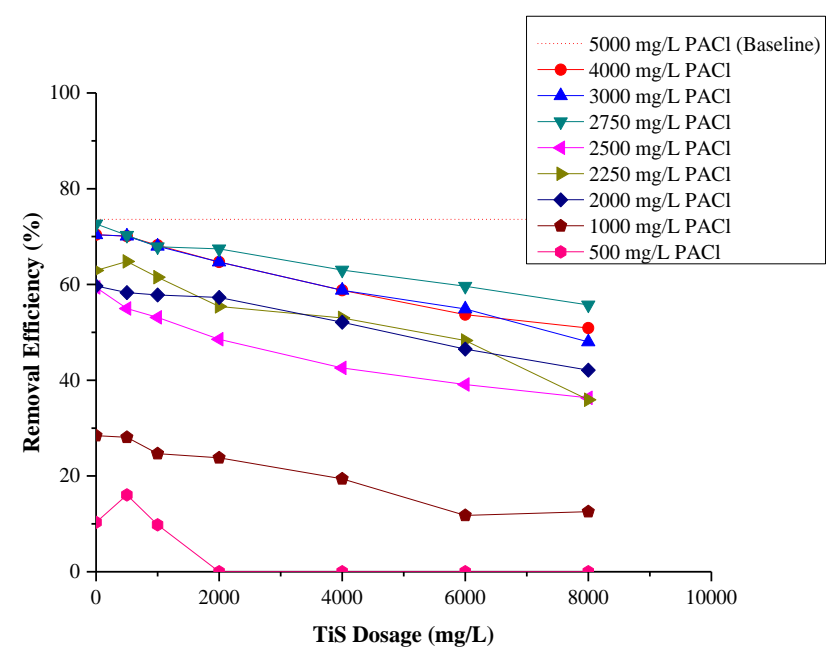

Figure 5. COD removal efficiency with varied dosage of $\mathrm{PACl}$ as coagulant and TiS as flocculant

\subsection{Efficiency of TiS as Flocculant}

A comparative analysis of the best combination of $\mathrm{PACl}$ and TiS obtained in Figs. 3, 4, and 5 was performed and reported in Fig. 6. From this figure, identical results were obtained for SS and color but a slightly different outcome was observed for COD. The removal efficiencies for SS and color removal differed by $0.02 \%$ and $0.01 \%$, respectively, which indicated non-significant differences. Lowering the amount of $\mathrm{PACl}$ by introducing TiS reduced the COD removal by $6.2 \%$. This slight difference remained within the acceptable range. In comparison of the overall performance of all the three removal parameters, with $2,000 \mathrm{mg} / \mathrm{L}$ of TiS, the amount of PACl usage for leachate treatment could be reduced from $5,000 \mathrm{mg} / \mathrm{L}$ to 2,750 $\mathrm{mg} / \mathrm{L}$, which would result in a $45 \%$ reduction in $\mathrm{PACl}$ dosage.

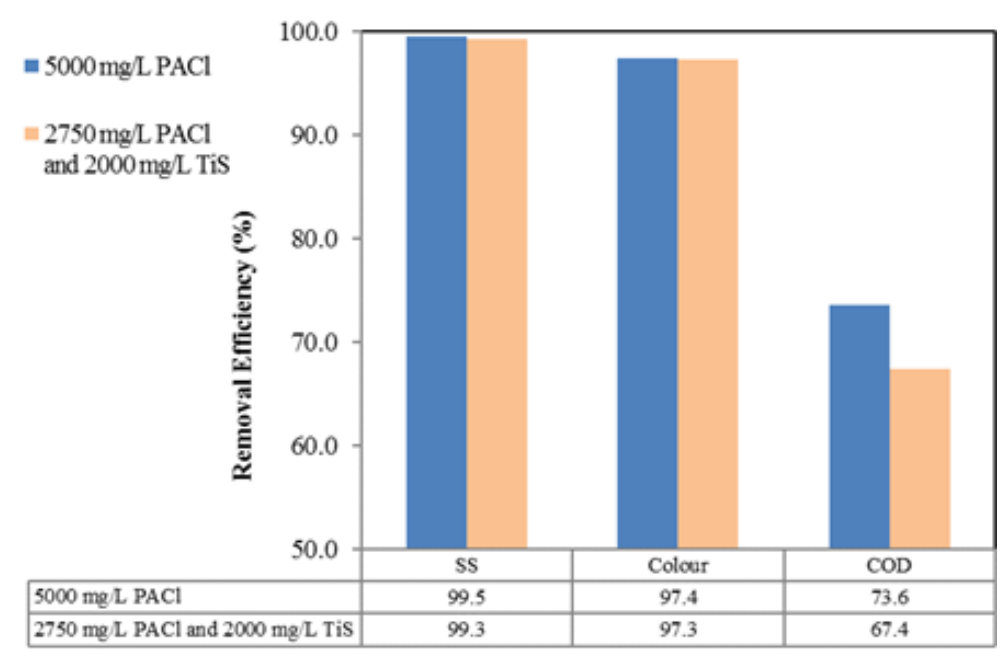

Figure 6. Comparison of pollutants removals at optimum conditions of PACl with and without TiS

The efficiency of TiS as the flocculant with $\mathrm{PACl}$ as the primary coagulant could be further proven through the performance of floc obtained from the coagulationflocculation process. Flocs obtained from the jar test with $5,000 \mathrm{mg} / \mathrm{L}$ of PACl and the combination of $2,750 \mathrm{mg} / \mathrm{L}$ of
$\mathrm{PACl}$ as coagulant and 2,000 $\mathrm{mg} / \mathrm{L}$ of TiS as flocculant were characterized and compared. No significant floc formed while using TiS as the sole coagulant in the jar test. The floc was characterized in terms of particle size. Figs. 7 and 8 show the floc sizes formed with different $\mathrm{PACl}$ dosages and 
a constant PACl dosage of $2,750 \mathrm{mg} / \mathrm{L}$ with different $\mathrm{TiS}$ dosages, respectively. From Fig. 7, the largest floc size was obtained by using a PACl dosage of $5,000 \mathrm{mg} / \mathrm{L}$ as the sole coagulant compared with other dosages with a floc size of $107.815 \mathrm{~m}$. Then, a gradual decrease in floc size with increasing applied dosages was observed. Fig. 8 presents the result of floc size formed when combining $2,750 \mathrm{mg} / \mathrm{L}$ of PACl as coagulant with $2,000 \mathrm{mg} / \mathrm{L}$ of TiS as flocculant. The largest floc size of $153.496 \mathrm{~m}$ was observed at 2,750 $\mathrm{mg} / \mathrm{L}$ of $\mathrm{PACl}$, which is consistent with the findings of Lin et al. (2013).

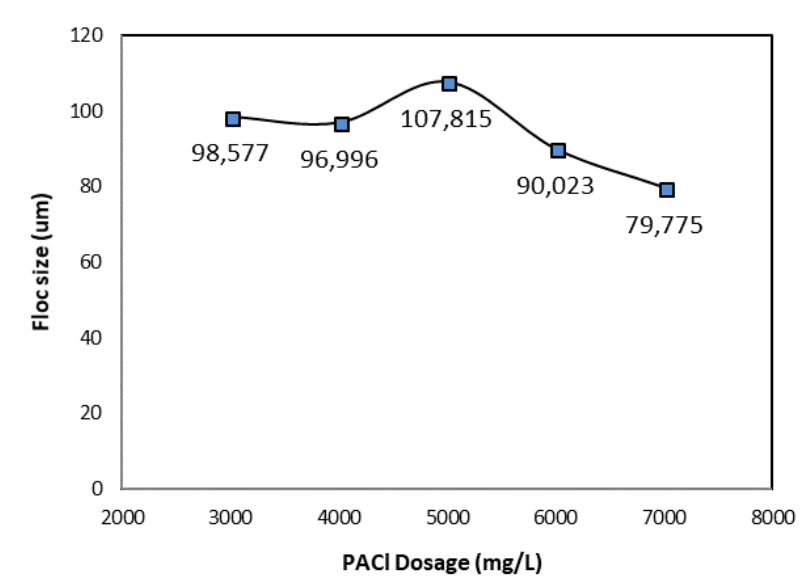

Figure 7. Size of floc formed by using various dosages of $\mathrm{PACl}$ as a sole coagulant

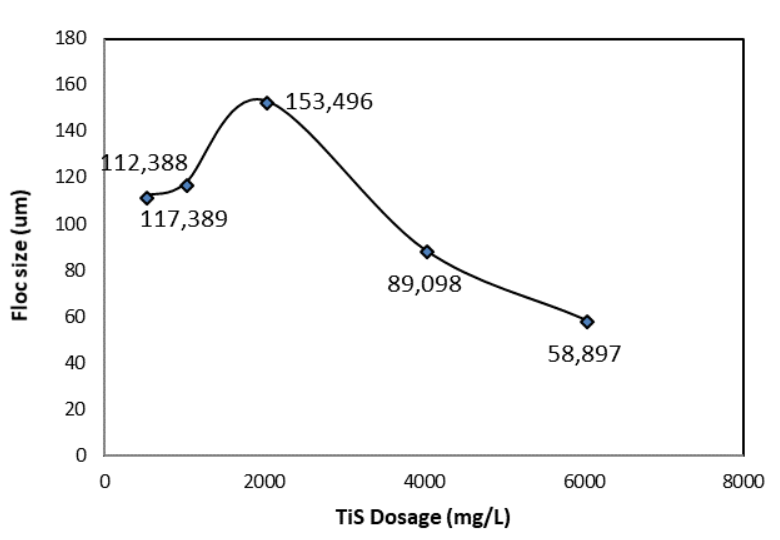

Figure 8. Size of floc formed by using $2,750 \mathrm{mg} / \mathrm{L} \mathrm{PACl}$ as a coagulant and various dosages of TiS as a flocculant

Fig. 9 presents the comparison of the particle sizes between two treatments and the raw leachate. The sizes of floc formed when combining $\mathrm{PACl}$ and TiS were considerably large compared with the particle size of the raw leachate, which indicated an effective floc formation. Effective floc formation would enhance floc performance, thereby further enhancing the efficient removal of pollutants. The floc size formed by applying the combination of $\mathrm{PACl}$ and TiS was larger than that when $\mathrm{PACl}$ was used alone. Thus, TiS aided in the aggregation of colloids and improved the performance of sludge settling. This result was due to the TiS having a high molecular weight, which was therefore able to provide long bridges during the mechanism of bridging in the flocculation process, as well as enhance the floc size (Amuda et al., 2006).

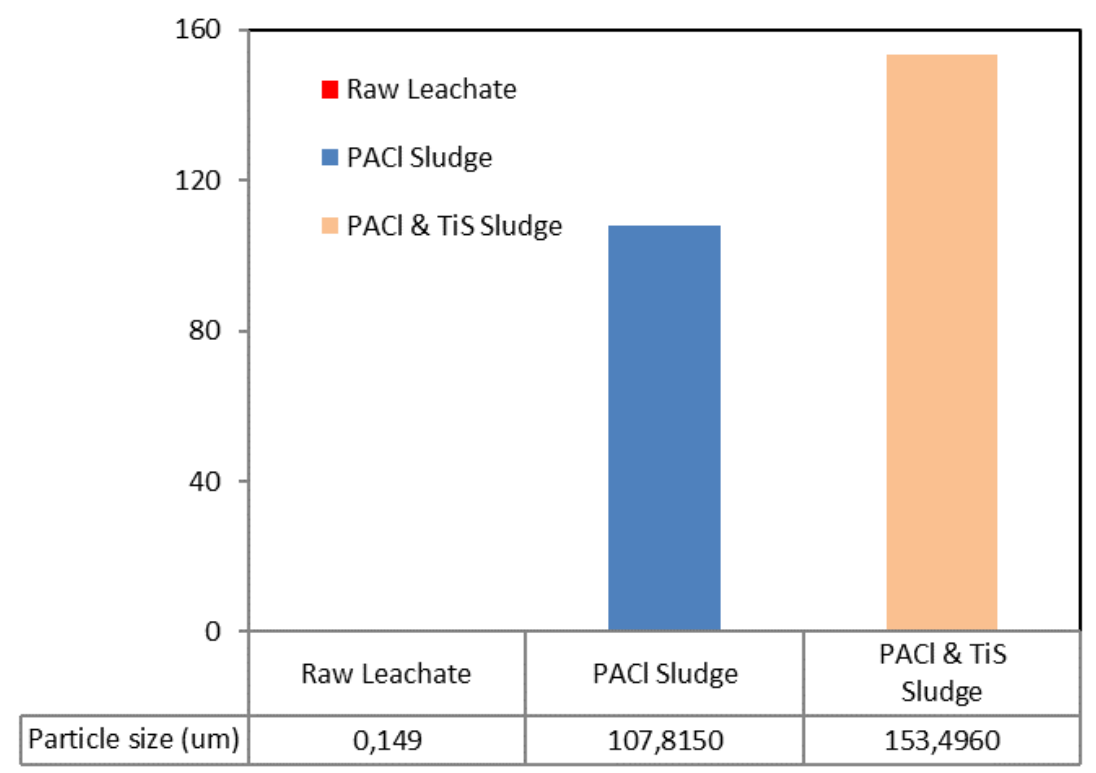

Figure 9. Comparison of particle size between raw leachate and sludge of $\mathrm{PACl}$ in the presence and absence of TiS

Generally, a flocculant with high molecular weight produces a relatively large floc size (Ebeling et al., 2005). The floc sizes recorded from the jar test were all smaller than $0.2 \mathrm{~mm}$. Hence, the organic part of the sludge decays rapidly with the increase in the quantity of finely dispersed and colloidal particles; this phenomenon will result in the decrease in the separation of water from the sludge and poor dewaterability (Turovsky and Mathai, 2006).

\subsection{Coagulant Cost Estimation}

Generally, the leachate treatment cost depends on factors, such as landfill design, quantity of leachate, level or degree 
of treatment needed, and final removal method for residues and effluent. Obtaining data on the cost of leachate treatment is difficult because it requires the cooperation of the company in charge. Therefore, on the basis of the chemicals used, the costs of both coagulants are estimated (Al-Shukaili and Agamuthu, 2008). Table 2 shows the cost comparisons when PACl was used alone and when TiS was used as the flocculant. From the comparisons, a cost of RM 7,800 was determined when $5,000 \mathrm{mg} / \mathrm{L}$ of PACl was used alone, whereas the use of $2,000 \mathrm{mg} / \mathrm{L}$ of TiS as flocculant only costed RM 4,646.

Table 2. Cost comparison

\begin{tabular}{cccccc}
\hline Coagulant & $\begin{array}{c}\text { Price of } \\
\text { Chemical (RM) }\end{array}$ & $\begin{array}{c}\text { Optimum } \\
\text { Concentration Used }\end{array}$ & $\begin{array}{c}\text { Amount of Chemical to } \\
\text { Treat 1 } \mathbf{m}^{\mathbf{3}} \text { of Leachate/day }\end{array}$ & $\begin{array}{c}\text { Cost to Treat } \mathbf{1} \mathbf{m}^{\mathbf{3}} \\
\text { of Leachate (RM) }\end{array}$ & $\begin{array}{c}\text { Total } \\
\text { (RM) }\end{array}$ \\
\hline $5000 \mathrm{mg} / \mathrm{L} \mathrm{PACl}$ & $300 / \mathrm{L}$ & $13 \mathrm{~mL} / 500 \mathrm{~mL}$ & $26 \mathrm{~L}$ & 7,800 & 7,800 \\
\hline $2750 \mathrm{mg} / \mathrm{L} \mathrm{PACl}$ & $300 / \mathrm{L}$ & $7.6 \mathrm{~mL} / 500 \mathrm{~mL}$ & $15.2 \mathrm{~L}$ & 4,560 & \multirow{2}{*}{4,646} \\
\hline $2000 \mathrm{mg} / \mathrm{L} \mathrm{TS}$ & $4.30 * / \mathrm{kg}$ & $10 \mathrm{~g} / 500 \mathrm{~mL}$ & $20 \mathrm{~kg}$ & 86 & \\
\hline
\end{tabular}

*1 RM = Ringgit Malysia = 3.91 USD, (Al-Shukaili and Agamuthu, 2008; Choenkwan et al., 2014)

\section{Conclusion}

Applying $\mathrm{PACl}$ as the sole coagulant at $\mathrm{pH} 6$ and concentration of $5,000 \mathrm{mg} / \mathrm{L}$ successfully removed $\mathrm{SS}$ (99.5\%), color (97.4\%), and COD (73.6\%), whereas $\mathrm{pH} 4$ and TiS dosage of $5,000 \mathrm{mg} / \mathrm{L}$ were identified as the optimum $\mathrm{pH}$ and coagulant dosage when TiS was used as the sole coagulant. This case resulted in color and SS removal of $41.9 \%$ and $5.9 \%$, respectively, whereas SS removal was found to be insignificant. At optimum operating conditions of $\mathrm{pH} 6$, when the combination of $\mathrm{PACl}$ and TiS was applied, such that $\mathrm{PACl}$ was used as the main coagulant and TiS as flocculant, $\mathrm{PACl}$ usage was reduced to $2,750 \mathrm{mg} / \mathrm{L}$ with the aid of $2,000 \mathrm{mg} / \mathrm{L}$ of TiS. The removal efficiencies achieved were $99.3 \%, 97.3 \%$, and $67.4 \%$ for SS, color, and COD, respectively, which were comparable to the treatment performance with the usage of $5,000 \mathrm{mg} / \mathrm{L}$ of $\mathrm{PACl}$. Therefore, TiS has the potential to be used as a natural coagulant/flocculant in landfill leachate treatment.

\section{Acknowledgment}

This research was funded by the Universiti Sains Malaysia (USM) under an iconic grant scheme (Grant no. 1001/CKT/870023) for research associated with the Solid Waste Management Cluster, Engineering Campus, USM, Malaysia.

\section{References}

Akinbile C.O., Ogunrinde A.T., Man H.C. and Aziz H.A. (2016), Phytoremediation of Domestic Wastewaters in Free water Surface Constructed Wetlands using Azolla pinnata, International Journal of Phytoremediation, 18(1), 54-61.

Akinbile C.O., Yusoff M.S., Zuki A.Z.A. (2012), Landfill Leachate Treatment Using Sub-surface Flow Constructed Wetland by Cyperus Haspan, Waste Management, 32, 1387-1393.

Al- Hamadani Y.J., Yusoff M.S., Umar M., Bashir M.J.K. and Adlan M.N. (2011), Apllication of psyllium husk as coagulant and coagulant aid in semi- aerobic landfill leachate treatment, Journal of Hazardous Materials, 190(1-3), 582-687. http://doi.org/10.1016/j.jhazmat.2011.03.087

Alias S., Akbar N.A. and Marajan C. (2010), Purifying wastewater for heavy metals removal using tamarind seed as natural coagulant, 3, 1-5.

Al-Shukaili M.M. and Agamuthu P. (2008), Coagulation and flocculation of Bukit Tagar sanitary landfill leachate using alum and PAC, Malaysian Journal of Science, 27(2), 39-51.

Amuda O.S., Amoo I.A. and Ajayi O.O. (2006), Performance optimization of coagulant/flocculant in the treatment of wastewater from a beverage industry, Journal of Hazardous Materials, 129(1-3),

69-72.

http://doi.org/10.1016/j.jhazmat.2005.07.078.

APHA. (2005). Standard Methods for the Examination of Water and Wastewater, 21st ed. American Public Health Association, Washington, D.C.

Aziz H.A. and Mojiri A. (Eds.). (2014). Wastewater engineering: Advanced wastewater treatment systems, Penang: IJSR Publication, Penang, Malaysia.

Aziz H.A., Alias S., Adlan M.N., Faridah, Asaari A.H. and Zahari, M.S. (2007), Colour removal from landfill leachate by coagulation and flocculation process, Bioresource Technology, 98(1), 218-220.

Aziz S.Q., Aziz H.A., Yusoff M.S. and Bashir M.J.K. (2011), Landfill leachate treatment using powdered activated carbon augmented sequencing batch reactor (SBR) process: optimization by response surface methodology, Journal of Hazardous Materials, 189, 404-413.

Bashir M.J.K., Aziz H.A., Yusoff M.S. and Adlan M.N. (2010), Application of response surface methodology (RSM) for optimization of ammoniacal nitrogen removal from semiaerobic landfill leachate using ion exchange resin, Desalination, 254(1-3), 154-161.

Choenkwan S., Fox J.M. and Rambo A.T. (2014), Agriculture in the mountains of northeastern Thailand: current situation and prospects for development, Mountain Research and Development, 34(2), 95-106.

Ebeling J.M., Rishel K.L. and Sibrell P.L. (2005), Screening and evaluation of polymers as flocculation aids for the treatment of aquacultural effluents, Aquacultural Engineering, 33(4), 235-249. http://doi.org/10.1016/j.aquaeng.2005.02.001

El-Salam M.M.A. and Abu-Zuid G.I. (2015), Impact of landfill leachate on the groundwater quality: A case study in Egypt, Journal of Advanced Research, 6(4), 579-586.

Foo K.Y. and Hameed B.H. (2009), An overview of landfill leachate treatment via activated carbon adsorption process, Journal of Hazardous Materials, 171(1-3), 54-60.

Kamaruddin M.A., Yusoff M.S., Aziz H.A. and Akinbile C.O. (2013), Recent Developments of Textile Waste Water Treatment by Adsorption Process: A Review, International Journal of Scientific Research in Knowledge, 1(4), 60-73.

Kamaruddin M.A., Yusoff M.S., Aziz H.A. and Hung Y.T. (2015), Sustainable treatment of landfill leachate, Applied Water Science, 5(2), 113-126.

Kos L. (2016), Use of Chitosan for Textile Wastewater Decolourization, Fibres and Textiles in Eastern Europe, 24(3), 130-135. 
Lee M.R. (2013), Treatment of landfill leachate in coagulationflocculation method by using micro zeolite and micro sand (Doctoral dissertation, Universiti Tun Hussein Onn Malaysia).

Lin Q., Peng H., Lin Q. and Yin G. (2013), Formation, breakage and re-formation of flocs formed by cationic starch, Water Science and Technology, 68(6), 1352-1358. http://doi.org/10.2166/wst.2013.377

Madhukar V. and Yogesh S. (2013), A comparative study of natural coagulants in flocculation of local clay suspensions of varied turbidities, Journal of Civil Engineering, 35(1), 26-39.

Maizatun M. (2011). Environmental law in Malaysia. Netherlands: Kluwer Law International.

Meraz K.A.S., Vargas S.M.P., Maldonado J.T.L., Bravo J.M.C., Guzman M.T.O., Maldonado and Mishra A.K., (Eds.) (2016). Flocculation performances of polymers and nanomaterials for the treatment of industrial wastewaters. Smart Materials for Waste Water Applications. 213-236.

Meraz Suarez K.A., Vargas Ponce S.A., Maldonado Lopez J.T., Bravo Cornejo J.M., Oropeza Guzman M.T. and Maldonado Lopez E.A. (2016), Eco-friendly innovation for nejayote coagulation-flocculation process using chitosan: Evaluation through zeta potential measurements, Chemical Engineering Journal, 284, 536-542.

Mokhtar S.M.Z., Wahab M.A., Selimin M.T. and Mohammad N.C. (2011), Landfill leachate treatment by a coagulationphotocatalytic process. 2011 International Conference on Environment and Industrial Innovation, 12, 224-228.

Murugan M. and Subramanian E. (2006), Studies on defluoridation of water by Tamarind seed, an unconventional biosorbent, Journal of Water and Health, 4(4), 453-461. http://doi.org/10.2166/wh.2006.014

Muyibi S.A., Johari M., Noor M. and Ahmadun F. (2002), Bench Scale Studies for Pretreatment of Sanitary Landfill Leachate with Moringa Oleifera Seeds Extract, International Journal of Environmental Studies, 59(5), 513-535. http://doi.org/10.1080/00207230212731

Omar F.M. (2015), Characterization, Properties, Transformations and Behaviour of ZnO Nanoparticles in Aquatic Systems, PhD Thesis, Univ. Genève, Switzerland

Phani Madhavi T. and Rajkumar R. (2013), Utilisation of natural coagulant for reduction of turbidity from waste water, International Journal of ChemTech Research, 5(3), 1119-1123.

Rajaram R., Siddiqui F.Z. and Khan M.E. (2011), From landfill gas to energy: Technologies and challenges. CRC Press, New York.

Santos T.R.T., Silva M.F., Nishi L., Vieira A.M.S., Klein M.R.F., Andrade M.B. and Bergamasco R. (2016), Development of a magnetic coagulant based on Moringa oleifera seed extract for water treatment, Environmental Science and Pollution Research, 23(8), 7692-7700.

Teh C.Y., Budiman P.M., Shak K.P.Y. and Wu T.Y. (2016), Recent advancement of coagulation-flocculation and its application in wastewater treatment, Industrial and Engineering Chemistry Research, 5(16), 4363-4389.

Turovskiy I.S. and Mathai P.K. (2006). Wastewater sludge processing. New Jersey, USA: John Wiley \& Sons, Inc.

Zainol N.A., Aziz H.A. and Ibrahim N. (2013), Treatment of Kulim and Kuala Sepetang Landfills Leachates in Malaysia using PolyAluminium Chloride (PACl), Research Journal of Chemical Sciences, 3(3), 52-57. 